\title{
Traditional and Complementary Medicine: Where are we?
}

\section{Serpil Demirag* \\ Adnan Menderes University, School of Medicine, Board Member of Traditional and Complementary Medicine Educational Center, Turkey}

Submission: May 20, 2019; Published: May 28, 2019

*Corresponding author: Serpil Demirag Adnan Menderes University, School of Medicine, Board Member of Traditional and Complementary Medicine Educational Center, Turkey

\section{Introduction}

As physical fitness and healthy diet are in, but not very easy to obtain and maintain, interest in Traditional and Complementary Medicine (TCM) is growing wider day by day. There are lots of synonym terms globally, but Turkish Ministry of Health accepts TCM officially. National Center for Complementary and Integrative Health $(\mathrm{NCCIH})$ divides TCM approaches into two main groups [1]: 1 . Natural products 2 . Mind and body practices. Among natural products, there are herbs, vitamins and minerals or dietary supplements. These are the most common approaches in USA, as well as the other countries [2]. In the second group, there are yoga, chiropractic, acupuncture, etc. Besides these two groups, there are also some other practices such as homeopathy, naturopathy and Ayurveda. World Health Organization (WHO) promotes the interventions that both improves the quality and standardization, and also facilitates the integration to health care systems [3]. WHO reports that in $80 \%$ of member countries, acupuncture is used and, is covered by health insurance, in $13 \%$ of them? In some member countries, TCM is the first line of health care, where in others, is complementary to the health care approaches because of the historical and cultural effects. Especially for physical Fitness, dietary supplements, lifestyle changes, chronic conditions and cancer care, TCM is used very common all over the world [2]. Despite the widespread use of TCM, physicians underestimate the TCM use by their patients [4].

In WHO Traditional Medicine Strategy Report 2014-2023, the goals were indicated as "to support Member States in:

a. Harnessing the potential contribution of TCM to health, wellness and people-centered health care.

b. Promoting safe and effective use of TCM through the regulation, evaluation and integration of TCM products, practices and practitioners into health systems, as appropriate" [3]. In this report, key strategies were mentioned as: i. To build the knowledge base for active management of TCM through appropriate national policies.

ii. To strengthen quality assurance, safety, proper use and effectiveness of TCM by regulating TCM products, practices and practitioners.

iii. To promote universal health coverage by integrating TCM services into health care service delivery and selfhealth care". For the second strategy, WHO suggests the countries to recognize the importance of regulations, education and training. According to this report, in 2012, 119 member countries reported that they have TCM policy and 69 members had TCM regulations on herbal products. 39 members were with TCM education at university level.

In most countries, health insurance does not cover TCM modalities, which means a huge amount of money out-of-pocket spending on TCM [5]. Other important issues about TCM are education/ training, safety and quality. Still in many countries, legislation, policy and educational issues cannot be solved or in progress.

\section{Turkey's Status}

In Turkey, which is one of the TCM use is very common, national policy and legislation are being established [6,7]. Although TCM Administrative Regulations were published by this Ministry in 2014 [8], Turkey is better far from many countries regarding policy and regulations [9]. Legislation on drugs was begin so long ago, but after European Union harmonized standards, it gets accelerated [10-12]. A department was established attached to the Ministry of health (Department of Traditional and Complementary Medical Applications), and as the interest in plant-origin-products increased, an Herbal Committee to registrate the herbal medicines was founded [13]. After Regulation on Pharmaceutical and Medicinal Products was published in 2003 [14], Regulation on Traditional Plant Medical 
Products was published in 2010 [15]. Besides, on March 9th 2019, Regulation on Clinical Researches of the Traditional and Complementary Medical Applications came into force [16]. By all these regulations, administration places, administrative people, administration criteria, administration and research rules were edited and being under control of the Ministry. Therefore, quality also can be obtained by interoperability. Although there are some efforts, health insurance coverage issue is still unresolved.

\section{Conclusion}

In conclusion, although there are some unresolved issues, Turkey has come a long way in the WHO instructions on traditional complementary medicine practices.

\section{References}

1. Integrative Health (2018).

2. Demirag SA (2013) Herbal medicine and cancer prevention: myth or not? OA Alternative Medicine 1(2): 16-20.

3. Traditional Medicine Strategy 2014-2023.

4. Giveon SM, Liberman N, Klang S, Kahan E (2003) A survey of primary care physicians' perceptions of their patients' uses of complementary medicine. Complementary Therapies in Medicine 11(4): 254-260.

5. Bodeker G, Kronenberg F (2002) A Public Health Agenda for Traditional, Complementary, and Alternative Medicine. American Journal of Public Health 92(10): 1582-1591.
6. Özçakır A, Aydın S (2007) Complementary/ Alternative Medicine Use in Primary Care. Research J Med Sci 1(1): 21-25.

7. Aydın S, Bozkaya AO, Mazıcıoğlu M, Gemalmaz A, Özçakır A, et al. (2008) What influences herbal medicine use? -prevalence and related factors. Turk J Med Sci 38(5): 455-463.

8. Regulation on Traditional and Complementary Medicine Practices.

9. Legal Status of Traditional Medicine and Complementary/Alternative Medicine: A Worldwide Review.

10. Akcan A, Demirag SA (2017) Factors for preferring OTC drugs in Aydin, Turkey. Trends Med 17: 1-4.

11. Gulpinar G, Ozcelikay G OTC (2019) Drug Regulations in Turkey: The Opinions of Community Pharmacists and Drug Industry.

12. Ersanli A, Özbal H (2019) Pharmaceutical Regulations Under Turkish Law.

13. Zhang X (2019) Regulatory Situation of Herbal Medicines A Worldwide Review.

14. Moroğlu ES, Arseven LLM (2019) Turkey: Pharmaceutical Regulations Under Turkish Law.

15. Regulation on Traditional Plant Medical Products.

16. Regulation on Clinical Researches of the Traditional and Complementary Medical Applications.

\section{Your next submission with Juniper Publishers} will reach you the below assets

- Quality Editorial service

- Swift Peer Review

- Reprints availability

- E-prints Service

- Manuscript Podcast for convenient understanding

- Global attainment for your research

- Manuscript accessibility in different formats

( Pdf, E-pub, Full Text, Audio)

- Unceasing customer service

Track the below URL for one-step submission https://juniperpublishers.com/online-submission.php 